\title{
DYNAMIC ANALYSIS OF PSC BOX GIRDER BRIDGE SUBJECTED TO TWO-WAY TRAFFIC
}

\author{
Mayuresh Vitthal Raut \\ Department of Civil Engineering \\ SCOE, Kharghar, Maharashtra, India
}

\author{
Prof. Dinesh Joshi \\ Department of Civil Engineering \\ SCOE, Kharghar, Maharashtra, India
}

\author{
Prof. Roshni John \\ Department of Civil Engineering \\ SCOE, Kharghar, Maharashtra, India
}

\begin{abstract}
Nowadays most efficient and economical structural system for bridge decks has been the Box Girder Bridges. However, in India sometimes bridges designed for one-way traffic may be used for temporary duration as a two-way traffic. In this project, threedimensional finite element analysis of a simply supported PSC box girder section for dead load and live load using four nodded shell elements is done to evaluate the effects. The structure is modeled and analyzed in ABAQUS software.

In this study, design of bridge girder is carried out taking one 70R tracked vehicle loading and for two-way traffic two 70R tracked vehicles are run simultaneously towards each other, from the opposite end of the girder. The results obtained show, the effects of loading, support and geometry of cross-section on the behavior in terms of development of normal stresses in different box girders. The design of box girder bridge is as per Indian Standard Specifications. It can be concluded from the present study that the introducing two-way traffic one one-way bridge induces more stresses and deflection in girder.

This study suggests that the variation of speed of vehicle from $30 \mathrm{kmph}$ to $50 \mathrm{kmph}$ does not show the significant difference in stress or deflection values. But the increase of span of girder from $20 \mathrm{~m}$ to $40 \mathrm{~m}$ have significant increase in stress and deflection values. It was observed that opening a one-way traffic bridge for temporarily two-way traffic usage in case of $40 \mathrm{~m}$ long girder, bridge girder may fail in serviceability criteria.
\end{abstract}

Keywords - PSC Box Girder Bridge, Two Way Traffic, IRC Class 70R Vehicle, Vehicle Speed.

\section{INTRODUCTION}

The increase in need of transportation necessitated the bridge construction over large and deep valleys. Also, bridges are needed to tackle various traffic problems by constructing different bypass roads resulting in efficient results. Economy, Aesthetic and convenience played major role leading to development of various type of bridges. In recent years, box girder bridges became a popular solution for medium and long span bridges in highway and railway transportation. This type of bridge is aesthetically pleasing and less vulnerable to environmental conditions comparatively. Also, this type of bridges reduces maintenance cost over life period. Methods of analysis also developed simultaneously in the last few decades. The development of digital computers enabled to analyze complex structural elements in different types of bridges and with different cross sections.

A box girder is made up of two web plates joined by common flange at top and bottom. The closed shell formed has more stiffness and strength than open cross sections. 'The box girders have different types based on the geometry of cross sections. Box girders evolved from single closed shells to the multiple closed shells of various shape like rectangular, circular, hexagonal, octagonal, etc. The box section is typical rectangular or trapezoidal with single or multiple closed shells. They are generally used in construction of long span bridges. In India, bridges are designed considering various types of different loads like dead load, live load, seismic load, wind load etc. The effect of live load i.e. vehicular load is considered as per guidelines provided by IS codes. Since design is done by considering impact factor, the actual impact on structure can be checked by simulating structural models in different software.

The bridges can be used as both one-way traffic and two-way traffic as per the actual requirements of the project. But there may some cases occur for temporal or longer duration where bridge designed for one-way traffic loading is subjected to two-way traffic loading. So, there should be estimated calculation to allow such type of uses of bridge girder. Hence the detailed study of such types of loading should be done to take proper precautionary measures or to avoid difficult situations.

\section{METHODOLOGY}

\section{A. Parameters -}

Dynamic analysis of 2-lane PSC box girder bridge designed for one-way traffic is done for loading conditions of two-way traffic. A standard cross-section shown in Fig.1 was opted for all cases while area of tendon is changed for the different span of girder, as per requirement. The analysis carried out is of girder having span of $20 \mathrm{~m}, 30 \mathrm{~m}$ and $40 \mathrm{~m}$ length, using IRC Class 70R loading. Vehicle speed of $30 \mathrm{kmph}, 40 \mathrm{kmph}$ and $50 \mathrm{kmph}$ was used to study the effect of two-way traffic on 


\section{International Journal of Engineering Applied Sciences and Technology, 2019 \\ Vol. 4, Issue 5, ISSN No. 2455-2143, Pages 148-188 \\ Published Online September 2019 in IJEAST (http://www.ijeast.com)}

each span lengths. Grade of concrete and steel used is M50 and Fe500 respectively.

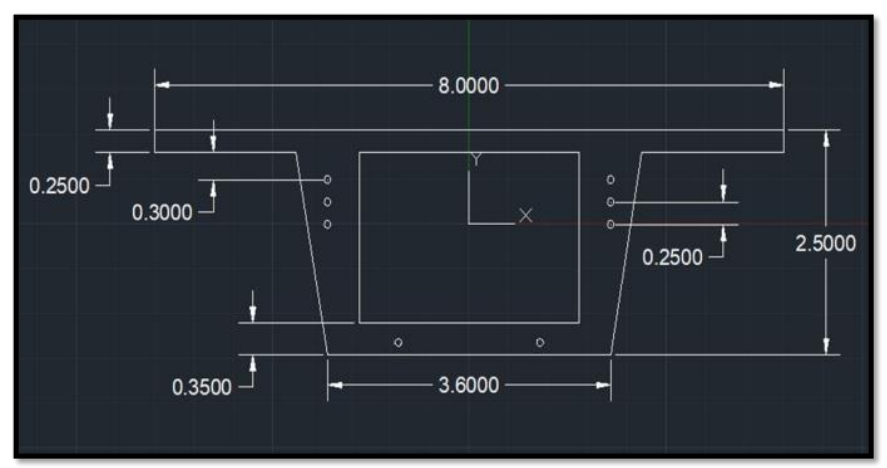

Fig. 1. Cross section of box girder with tendon positions at end section

\section{B. Live Load -}

$>$ For bridges classified under IRC: 6-2016 Clause 201.1, the design live load shall consist of standard wheeled or tracked vehicles or trains. There are four main types of loading:
1. IRC Class 70R Loading
2. IRC Class AA Loading
3. IRC Class A Loading
4. IRC Class B Loading

$>$ In this analysis of box girder IRC Class70R Tracked Vehicle Loading is used at a vehicle speed of $50 \mathrm{kmph}$.

$>$ Vehicle loading is placed at the center of the girder crosssection and then moved along the span of the girder for one-way traffic and for two-way traffic two identical vehicles are moved simultaneously from both ends of girder towards each-others.

$>$ Fig. 2. shows the loading configuration for IRC Class 70R Vehicle.

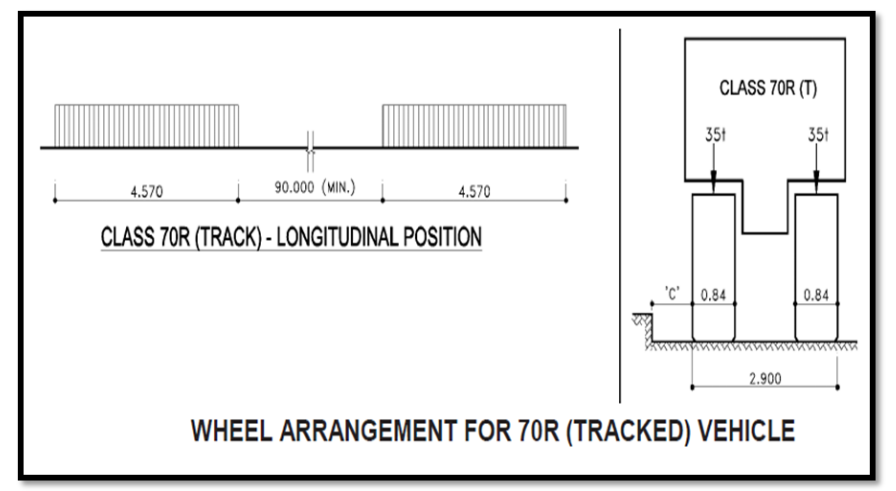

Fig. 2. IRC Class 70R Vehicle.

\section{As per IRC 6: 2016 clause 204.1.1-}

$>$ The nose to tail spacing between two successive vehicles shall not be less than $90 \mathrm{~m}$ for tracked vehicle.

$>$ For multi-lane bridges and culverts, each Class 70R loading shall be considered to occupy two lanes and no other vehicle shall be allowed in these two lanes. The passing/crossing vehicle can only be allowed on lanes other than these two lanes.

$>$ Class 70R loading is applicable only for bridges having carriageway width of $5.3 \mathrm{~m}$ and above. The minimum clearance between the road face of kerb and the outer edge of the wheel or track, ' $\mathrm{C}$ ', shall be $1.2 \mathrm{~m}$.

\section{As per IRC 6: 2016 clause 204.3 -}

$>$ As per IRC, for each two-lane of carriageway, one 70R vehicle loading is adopted for design and the same live load combination suggested by IRC 6: 2016 is shown in Table 1.

Table 1. Live Load combinations for two lane bridge as per IRC 6: 2016 (Table 6).

\begin{tabular}{|c|c|c|c|}
\hline $\begin{array}{c}\text { Sr. } \\
\text { No. }\end{array}$ & $\begin{array}{c}\text { Carriageway Width } \\
\text { (CW) }\end{array}$ & $\begin{array}{c}\text { Number of } \\
\text { Lanes for } \\
\text { Design } \\
\text { Purposes }\end{array}$ & Load Combination \\
\hline 1$)$ & Less than $5.3 \mathrm{~m}$ & 1 & $\begin{array}{c}\text { One lane of Class A } \\
\text { considered to } \\
\text { occupy } 2.3 \mathrm{~m} \text {. The } \\
\text { remaining width of } \\
\text { carriageway shall } \\
\text { be loaded with 500 } \\
\text { kg/m2 }\end{array}$ \\
\hline 2$)$ & $\begin{array}{c}5.3 \mathrm{~m} \text { and above but } \\
\text { less than } 9.6 \mathrm{~m}\end{array}$ & 2 & $\begin{array}{c}\text { One lane of Class } \\
\text { 70R OR two lanes } \\
\text { for Class A }\end{array}$ \\
\hline
\end{tabular}

\section{RESULTS AND DISCUSSIONS}

The results were obtained by bridge girders of span $20 \mathrm{~m}, 30$ and $40 \mathrm{~m}$ subjected to the vehicle speed of $30 \mathrm{kmph}, 40 \mathrm{kmph}$ and $50 \mathrm{kmph}$ for two-way traffic. Then it is compared with the span bridge span and vehicle speed of $50 \mathrm{kmph}$ subjected to one-way traffic. The comparison is based on the values of maximum compressive stress and maximum deflection at the mid-section of girder.

The comparison of maximum deflection of one-way and twoway traffic for $20 \mathrm{~m}, 30 \mathrm{~m}$ and $40 \mathrm{~m}$ span is shown in figure (a), (c) and (e) respectively.

The comparison of maximum stress of one-way and two-way traffic for $20 \mathrm{~m}, 30 \mathrm{~m}$ and $40 \mathrm{~m}$ span is shown in figure (b), (d) and (f) respectively. 
International Journal of Engineering Applied Sciences and Technology, 2019

Vol. 4, Issue 5, ISSN No. 2455-2143, Pages 148-188

Published Online September 2019 in IJEAST (http://www.ijeast.com)

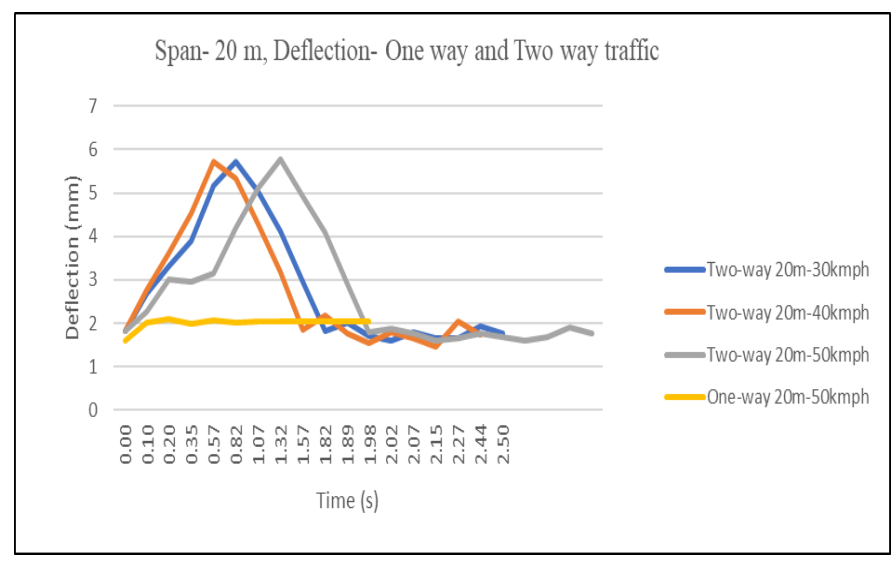

(a)

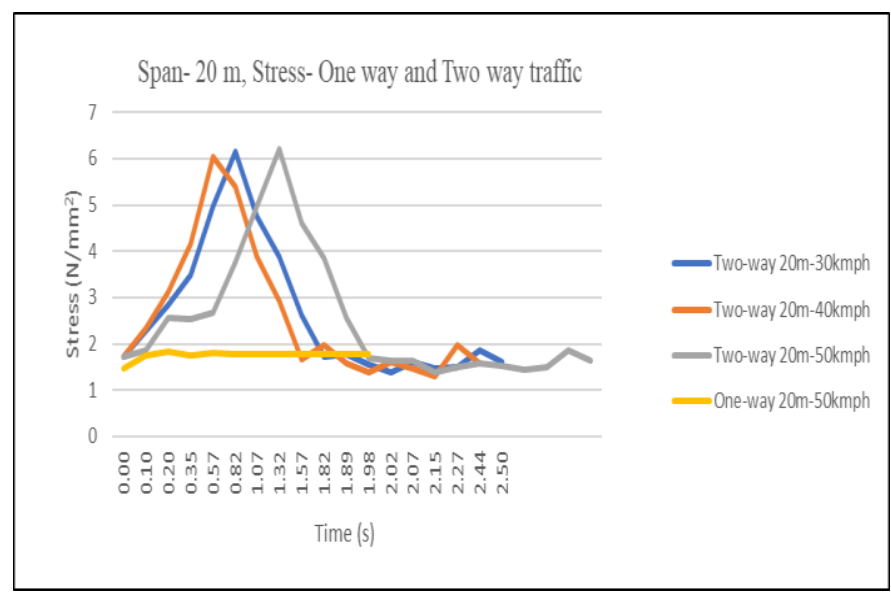

(b)

Fig 3 (a) Maximum Deflection for $20 \mathrm{~m}$ span (b) Maximum Stress for $20 \mathrm{~m}$ span

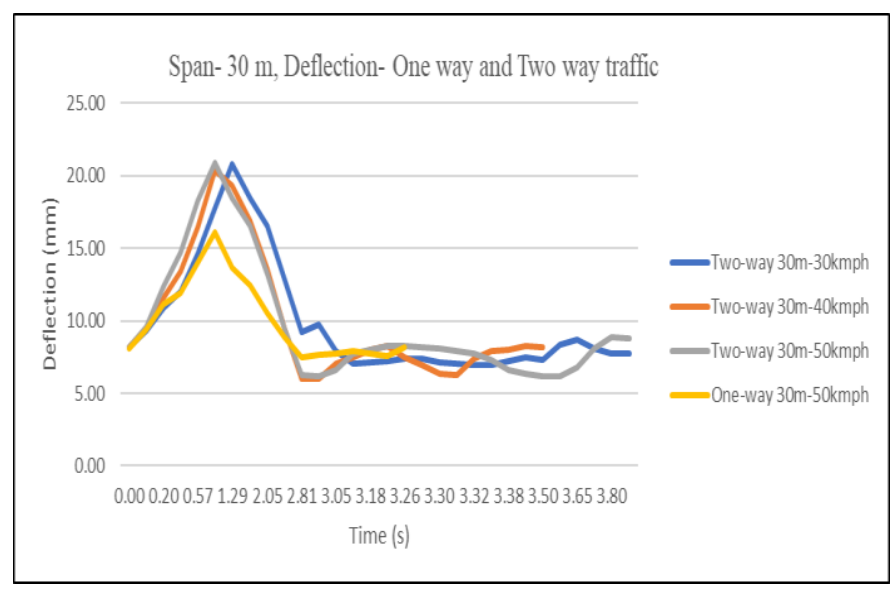

(a)

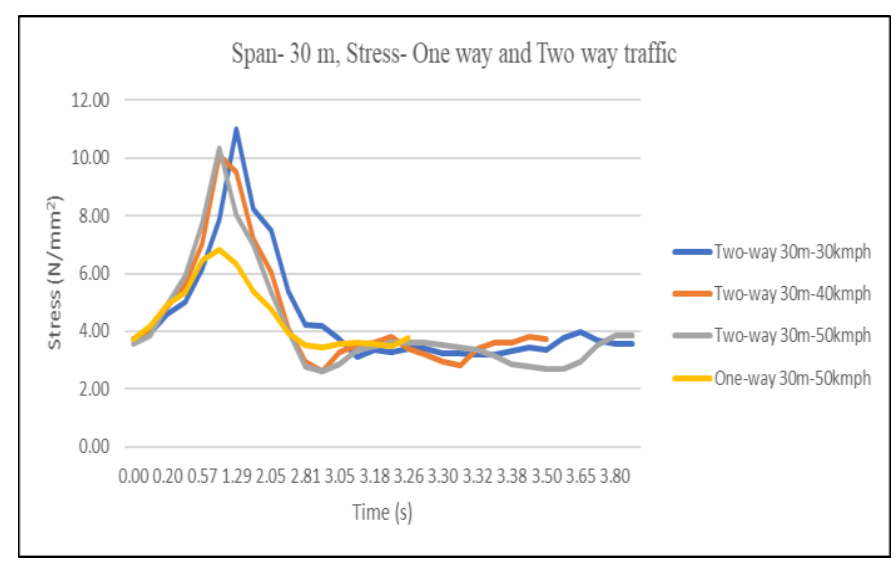

(b)

Fig 4 (a) Maximum Deflection for $30 \mathrm{~m}$ span (b) Maximum Stress for $30 \mathrm{~m}$ span

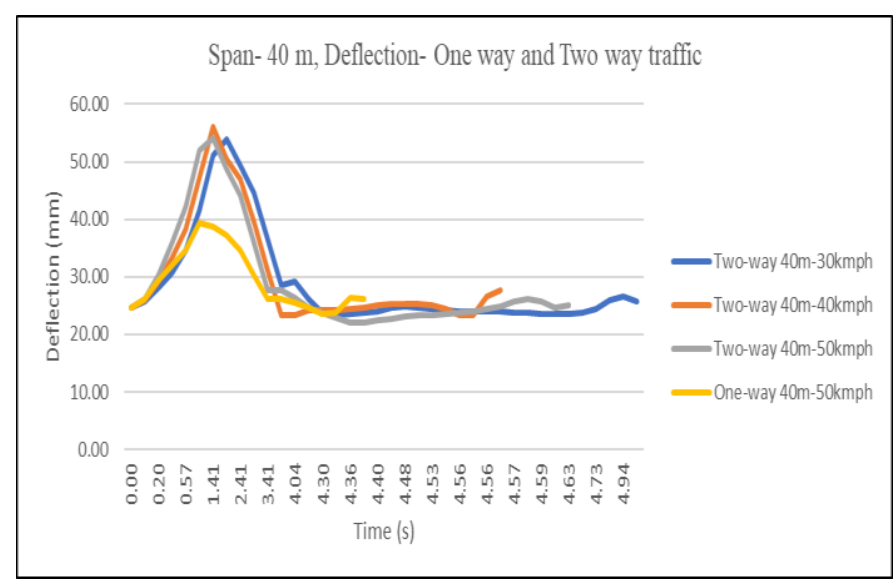

(a)

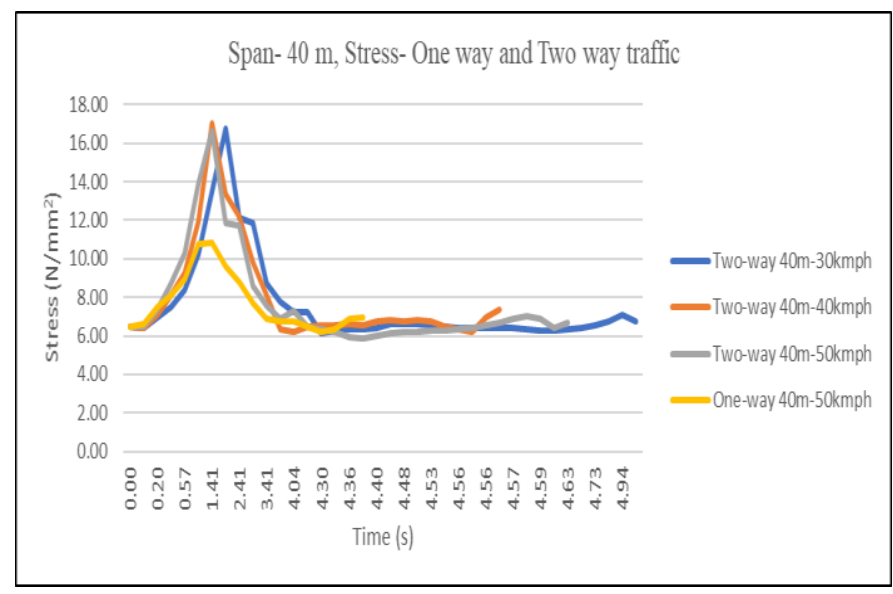

(b)

Fig 5 (a) Maximum Deflection for $40 \mathrm{~m}$ span (b) Maximum Stress for $40 \mathrm{~m}$ span 
Table -2 Results for $20 \mathrm{~m}$ span

\begin{tabular}{|c|c|c|c|}
\hline \multirow{2}{*}{ Specification } & \multicolumn{3}{|c|}{ For $20 \mathrm{~m}$ girder } \\
\cline { 2 - 4 } & $50 \mathrm{kmph}$ & $40 \mathrm{kmph}$ & $30 \mathrm{kmph}$ \\
\hline Maximum Deflection $(\mathrm{mm})$ & \multicolumn{3}{|c|}{ (Permissible Deflection $=25 \mathrm{~mm})$} \\
\hline Two-way & 6.17 & 6.01 & 6.01 \\
\hline One-way & 2 & $\ldots$ & $\ldots$ \\
\hline Compressive Stress $\left(\mathrm{N} / \mathrm{mm}^{2}\right)$ & \multicolumn{3}{|c|}{$\left(\right.$ Permissible Stress $\left.=24 \mathrm{~N} / \mathrm{mm}^{2}\right)$} \\
\hline Two-way & 6.21 & 6.04 & 6.15 \\
\hline One-way & 1.83 & --- & --- \\
\hline
\end{tabular}

Table -3 Results for $30 \mathrm{~m}$ span

\begin{tabular}{|c|c|c|c|}
\hline \multirow{2}{*}{ Specification } & \multicolumn{3}{|c|}{ For $30 \mathrm{~m}$ girder } \\
\cline { 2 - 4 } & $50 \mathrm{kmph}$ & $40 \mathrm{kmph}$ & $30 \mathrm{kmph}$ \\
\hline Maximum Deflection $(\mathrm{mm})$ & \multicolumn{3}{|c|}{ (Permissible Deflection $=37.5 \mathrm{~mm})$} \\
\hline Two-way & 20.86 & 20.5 & 20.4 \\
\hline One-way & 16.14 & $\ldots$ & $\ldots$ \\
\hline Compressive Stress $\left(\mathrm{N} / \mathrm{mm}^{2}\right)$ & $\left(\right.$ Permissible Stress $\left.=24 \mathrm{~N} / \mathrm{mm}^{2}\right)$ \\
\hline Two-way & 10.33 & 10 & 11 \\
\hline One-way & 6.82 & --- & $\ldots-$ \\
\hline
\end{tabular}

Table -4 Results for $40 \mathrm{~m}$ span

\begin{tabular}{|c|c|c|c|}
\hline \multirow{2}{*}{ Specification } & \multicolumn{3}{|c|}{ For $40 \mathrm{~m}$ girder } \\
\cline { 2 - 4 } & $50 \mathrm{kmph}$ & $40 \mathrm{kmph}$ & $30 \mathrm{kmph}$ \\
\hline Maximum Deflection $(\mathrm{mm})$ & (Permissible Deflection $=50 \mathrm{~mm})$ \\
\hline Two-way & 54.8 & 56.2 & 54.6 \\
\hline One-way & 41.2 & $\ldots$ & $\ldots$ \\
\hline Compressive Stress $\left(\mathrm{N} / \mathrm{mm}^{2}\right)$ & \multicolumn{3}{|c|}{$\left(\right.$ Permissible Stress $\left.=24 \mathrm{~N} / \mathrm{mm}^{2}\right)$} \\
\hline Two-way & 16.64 & 17 & 16.8 \\
\hline One-way & 10.8 & --- & $\ldots$ \\
\hline
\end{tabular}

Table -2 , Table -3 and Table -4 shows the values of maximum deflection and maximum stress at the mid-span of the $20 \mathrm{~m}, 30 \mathrm{~m}$ and $40 \mathrm{~m}$ span girder, respectively. There is significant increase of values observed of each cases. All the values of maximum stress obtained in case of one-way and two-way traffic are in the permissible limit as per IS code. Deflection for $20 \mathrm{~m}$ and $30 \mathrm{~m}$ span is in the permissible lmit for both loading cases, but deflction obtained for $40 \mathrm{~m}$ span under two-way traffic loading found to be exceeding the permissible limit suggested by IS code.

\section{CONCLUSION}

1. From the values of deflection found out for various span and speed (of vehicle) combination, we can conclude that the deflection for top and bottom slab is almost similar in every case.

2. There is no significant increase of deflection observed with increase in the speed of vehicle ranging from 30 kmph to $50 \mathrm{kmph}$.

3. As span of bridge girder increases there is significant increase in deflection of middle span which is as large as 3.38 times for $20 \mathrm{~m}$ to $30 \mathrm{~m}$ increase, 9.1 times for $20 \mathrm{~m}$ to $40 \mathrm{~m}$ increase and 2.69 times for $30 \mathrm{~m}$ to $40 \mathrm{~m}$ increase for two-way traffic.

4. The maximum deflection found out for various span are:

a) For $20 \mathrm{~m}$ span girder, maximum deflection is $2 \mathrm{~mm}$ for one-way traffic and $6 \mathrm{~mm}$ for two-way traffic which is below the deflection limit of $25 \mathrm{~mm}$ for $20 \mathrm{~m}$ span.

b) For $30 \mathrm{~m}$ span girder, maximum deflection is 16.14 $\mathrm{mm}$ for one-way traffic and $20.86 \mathrm{~mm}$ for two-way traffic which is below the deflection limit of $37.5 \mathrm{~mm}$ for $30 \mathrm{~m}$ span.

c) For $40 \mathrm{~m}$ span girder, maximum deflection is 39.59 $\mathrm{mm}$ for one-way traffic and $56.2 \mathrm{~mm}$ for two-way traffic which is above the deflection limit of $50 \mathrm{~mm}$ for $40 \mathrm{~m}$ span.

5. Maximum compressive stress generated at the middle span of bottom slab of the girder is increased with increase in the span length which is as large as $77 \%$ for $20 \mathrm{~m}$ to 30 $\mathrm{m}, 173.7 \%$ for $20 \mathrm{~m}$ to $40 \mathrm{~m}$ and $54.54 \%$ for $30 \mathrm{~m}$ to $40 \mathrm{~m}$ for two-way traffic.

6. The maximum compressive stresses generated at the middle span of bottom slab foe two-way traffic are 6.21 $\mathrm{N} / \mathrm{mm}^{2}$ for $20 \mathrm{~m}, 11 \mathrm{~N} / \mathrm{mm}^{2}$ for $30 \mathrm{~m}$ and $17 \mathrm{~N} / \mathrm{mm}^{2}$ for 40 $\mathrm{m}$ span which is less than the limiting value of $24 \mathrm{~N} / \mathrm{mm}^{2}$ for M50 grade concrete.

7. Also, it is found that the tensile stress generated at the middle span of top slab for all span is fluctuating at different values but is in the limit of tensile strength of concrete which is $4.94 \mathrm{~N} / \mathrm{mm}^{2}$ for M50 grade concrete.

\section{REFERENCE}

[1] IRC 6 (2016), "Standard Specification and code of practice for Road Bridges.", Indian Roads Congress

[2] IRC 112 (2011). "Code of practice for concrete road bridges." Indian Roads Congress.

[3] Hai Zhong, Mijia Yang, Zhili Gao (2015). "Dynamic response of prestressed bridge and vehicle through bridge-vehicle interaction analysis." Engineering Structures 87 (pp.116-125).

[4] Bin Chen, Ze-nan Ye, Zengshun Chen, Xu Xie (2018). "Bridge vehicle load model on different grades of roads in China based on Weigh-in-Motion (WIM) data" Measurement 122 (pp.670-678). 


\section{International Journal of Engineering Applied Sciences and Technology, 2019 \\ Vol. 4, Issue 5, ISSN No. 2455-2143, Pages 148-188 \\ Published Online September 2019 in IJEAST (http://www.ijeast.com)}

[5] L. Maa, W. Zhanga, W.S. Hanb, J.X. Liu (2018). "Determining the dynamic amplification factor of multispan continuous box girder bridges in highways using vehicle-bridge interaction analyses." Engineering Structures 181 (pp.47-59).

[6] Andrew Lansdell, Wei Song, Brandon Dixon (2017). "Development and testing of a bridge weigh-in-motion method considering nonconstant speed." Engineering Structures 152 (pp.709-726).

[7] Y.B. Yang, Bin Zhang, Tianyi Wang, Hao Xu, Yuntian Wu (2018) "Two-axle test vehicle for bridges: Theory and applications." International Journal of Mechanical Sciences 152 (pp.51-62).

[8] T. L. Wang, M. Shahawy and D. Z. Huan (1991). "Impact in Highway Prestressed Concrete Bridges" Computers and Structures Vol. 44, No.3, (pp.525-534).

[9] Khanh Nguyen Gia, Jose M. Goicolea (2017). "Vibration analysis of short skew bridges due to railway traffic using analytical and simplified models." Procedia Engineering 199 (pp.3039-3046).

[10]R. Wodzinowski, K. Sennah, H. M. Afefy (2018). "Free vibration analysis of horizontally curved composite concrete-steel I-girder bridges." Journal of Constructional Steel Research 140 (pp.47-61).

[11] T. Nagayama, A. P. Reksowardojo, D. Su, T. Mizutani (2017). "Bridge natural frequency estimation by extracting the common vibration component from the responses of two vehicles." Engineering Structures 150 (pp.821-829).

[12] Daniel Cantero, Mahir Ülker-Kaustell, Raid Karoumi (2016). "Time-frequency analysis of railway bridge response in forced vibration." Mechanical Systems and Signal Processing 76-77 (pp.518-530).

[13] Y. Deng, B. M. Phares, L. Greimann, Gus L. Shryack, Jerad J. Hoffman (2015). "Behavior of curved and skewed bridges with integral abutments." Journal of Constructional Steel Research 109 (pp.115-136).

[14] Qing Zeng, Y. B. Yang, Elias G. Dimitrakopoulos (2016). "Dynamic response of high-speed vehicles and sustaining curved bridges under conditions of resonance." Engineering Structures 114 (pp.61-74).

[15] Nina Serdar and Radomir Folic (2016). "Comparative analysis for modal responses for reinforced concrete (RC) straight and curved bridges." Procedia Engineering 156 (pp.403-410).

[16] S. J. Fatemi, M. S. Mohamed Ali, A. H. Sheikh (2015). "Load distribution for composite steel-concrete horizontally curved box girder bridge." Journal of Constructional Steel Research 116 (pp.19-28).

[17] Junwon Seo and Daniel G. Linzell (2011). "Seismic vulnerability assessment of Horizontally curved steel bridge." Engineering Structures 34 (pp.21-32).

[18] Daniel Cantero, David Hester, James Brownjohn (2017). "Evolution of bridge frequencies and modes of vibration during truck passage." Engineering Structures 152 (pp.452-464).

[19] Nina Serdar, Radomir Folic (2018). "Vulnerability and optimal probabilistic seismic demand model for curved and skewed RC bridges." Engineering Structures 176 (pp.411-425).

[20]E. Omranian, Adel E. Abdelnaby, G. Abdollahzadeh (2018). "Seismic vulnerability assessment of RC skew bridges subjected to mainshock-aftershock sequences." Soil Dynamics and Earthquake Engineering 114 (pp.186197). 